\title{
Structure and level of investment expenditures and the work efficiency in agricultural activities in the Małopolskie province
}

\author{
Katarzyna Grotkiewicz ${ }^{1, *}$ and Semjons Ivanovs $^{2}$ \\ ${ }^{1}$ University of Agriculture in Krakow, Faculty of Production and Power Engineering1, ul. Balicka \\ 116B, 30-149, Poland \\ ${ }^{2}$ Agency of Łatvia University of Agricultural, Research Institute of Agricultural Machinery \\ 1. Instituta Str., Ulbroka, Stopinu area, LV-2130, Latvia
}

\begin{abstract}
The purpose of the study was to determine the scale and importance of the investments in technical production inputs in the form of replacement value of the machine park, made in agricultural activities with regard to improvement of their productivity. The study was carried with regard to the period between 2011-2016. The scope of the thesis referred to 30 individual farms located within the territory of the Małopolskie province. The studies carried out proved a positive impact of the investment expenditures with regard to the replacement value of the machine park on the increase in work efficiency in agriculture.
\end{abstract}

\section{Introduction}

The agricultural production assumes to use specific resources of production factors that are classified in agriculture into three most important groups, such as: labor, land and capital. This division is simplified, however, the analysis of labor resources, land and capital as well as their structure and dependencies between them is sufficient to determine the agriculture development opportunities [1,2].

The enterprises' operation in the agricultural sector is associated with the constant increase in competitiveness as well as improvement of production efficiency [3, 4]. In order to meet the requirements that are the implication of the ongoing changes, actions ensuring longterm development are needed. Proper investment activities in technical production inputs that in the long-term perspective have impact on the achieved econometric results due to the business operations constitute, among others, their basis [5]. The issue of proper management of technical production inputs in the business activity focused on maximizing profit in accordance with the principles of sustainable development was the subject of many discussions and scientific studies [6-8].

Poland's accession to the European Union, by launching a number of investment financing options, contributed to the improvement of the quality of Polish agriculture, being one of the elements of its development. Equipping farms with fixed assets was better, therefore farms became more modern and raised their competitiveness. According to data of the Central Statistics Office [9], investment expenditures in the agriculture and hunting sector

\footnotetext{
* Corresponding author: k.grotkiewicz@urk.edu.krakow.pl
} 
between 2005-2016 amounted to nearly PLN 49.5 billion, and their average annual value increased from PLN 2.4 billion in 2005 to over 5.0 PLN billion in 2016. However, the level of investments in farms was varied.

According to Sadowski [10,11], new challenges and opportunities for Polish agriculture were the potential causes of structural transformation of particular economic sectors, including agriculture, which due to its specificity reacts specifically not only to the economic situation, but also to economic policy measures.

With regard to the changes that take place in Poland, it may be noticed that the efficiency of management, which shapes the image of the Polish sector, proves the increase rate of GDP index. In the first quarter of 2019, the Gross Domestic Product of Poland was actually higher by $4.7 \%$ compared to the same period of the previous year [12]. The main factor of this economic growth encompasses domestic demand with annual growth at the level of $4.2 \%$. The economic growth rate also resulted from the increase in total consumption as well as in the household sector (GUS). The development of investment projects may also be observed in the structure of fixed investments in Polish agriculture. According to data of the Central Statistical Office [9], the value of investment expenditures in the national economy was over PLN 250 billion, including expenditure on: buildings and structures - PLN 133 billion (51.7\%), machinery, technical equipment and tools - PLN 90 billion (34.8\%), transport means - PLN 33 billion (12.7\%). It is worth stressing that the transformation of farms in Poland is very disintegrated with regard to their sizes: from one hectare to several thousand hectares $[13,14]$. What is more, agriculture in Poland is characterized by a significant number of persons involved in work, preservation of soils of medium and low agricultural suitability as well as both relatively low consumption of industrial production means. Despite that, Poland is an important manufacturer of numerous products of animal origin, soil products and horticultural products in Europe and in the world [15].

The growing proportions of production factors per unit of work stimulate development and are associated with the growing scale of production, improvement of technology and innovation, and thus raised work efficiency with environmental conditions kept $[6,16]$. According to the authors $[6,17]$, work efficiency is implied by technical infrastructure, capital productivity, and land-to-work relations (concentration ratio) and land productivity. Achievements related to changes in agricultural activity undoubtedly contribute to the improvement of market position and growing profitability through the increase in the economic size of a farm, in particular due to modernization of agricultural production with regard to the analyzed production factors and, in particular, capital incurred for improvement of technical infrastructure with technical production inputs in the agricultural sector.

\section{Purpose, scope of the study, methodology}

The purpose of the study was to determine the structure and scale of investments in technical production inputs in the form of a replacement value of the machine park, made in agricultural activities with regard to improvement of their productivity. The study was carried out in the form of a directive interview, and the scope of work included 30 individual farms located within the territory in the Dąbrowski local administration unit in the Małopolskie province. The analyzed farms were divided into three area groups. The first group consisted of farms with the area of 1-20 ha ( 9 farms), the second group referred to the farms with the area of 21-70 ha (11 farms), and the third group encompassed objects with the area of 71 ha and more (10 farms). The study concerned the years 2011 to 2016, which allowed for the characterization of changes that occurred in individual farms. On the basis of the directive interview, the following values were determined and calculated: area of cropland, technical equipment of farms with technical means, year and value of purchase 
of technical means and their use, as well as labor input in agriculture. With regard to the collected data, the value of clean production, the replacement value of the machine park and the labor productivity index calculated by the ratio of clean production to man-hours on a farm were calculated.

\section{Results analysis}

On the basis of the directive interview made among the analyzed farms, it was set that the main economic profile was focused on the plant production run. The majority of agricultural activities included cereal crops (table 1).

Based on the directive interview in Table 1, the average area of cropland in the analyzed individual farms in the examined years was presented based on the area of the farm of owners. On the basis of the studies carried out, among 30 individual farms, clear changes regarding the increased average agricultural area in the analyzed groups of farms were observed. The largest area of cropland in 2011 as well as in 2016 was owned by farmers belonging to the group of large farms (71 ha and more). In 2011, cropland was 24.16 [ha] on the average, however, in 2016, it was approx. 54.17 [ha] on the average.

The increased are-based structure further contributed to the improvement of other production factors that determine the level of intensity and competitiveness of the agricultural sector, which will be presented later in this article.

Table 1. Average area of cropland between 2011-2016 [ha]

\begin{tabular}{|c|c|c|c|c|c|c|}
\hline \multirow{2}{*}{ Item } & \multirow{2}{*}{\multicolumn{2}{|c|}{ Specification }} & \multirow[b]{2}{*}{ On the average } & \multicolumn{3}{|c|}{ Farms: } \\
\hline & & & & Small & Medium-sized & Large \\
\hline \multicolumn{7}{|c|}{ Year 2011} \\
\hline \multirow[t]{5}{*}{1} & \multirow{5}{*}{$\begin{array}{l}\text { Arable land } \\
\text { including: }\end{array}$} & & 21.56 & 7.27 & 22.00 & 33.95 \\
\hline & & Cereals & 16.53 & 5.86 & 16.30 & 26.40 \\
\hline & & Root crops & 1.00 & 0.41 & 1.34 & 1.15 \\
\hline & & Fodder crops & 2.17 & 0.67 & 3.45 & 2.10 \\
\hline & & $\begin{array}{l}\text { Industrial } \\
\text { Vegetables }\end{array}$ & 1.87 & 0.33 & 0.91 & 4.30 \\
\hline 2 & \multicolumn{2}{|l|}{ Grassland } & 2.35 & 1.37 & 2.15 & 3.45 \\
\hline 3 & \multicolumn{2}{|c|}{ Orchard and plantations } & 0.24 & 0.03 & 0.05 & 0.65 \\
\hline 4 & \multicolumn{2}{|c|}{ Arable land in total } & 24.16 & 8.67 & 24.20 & 38.05 \\
\hline \multicolumn{7}{|c|}{ Year 2016} \\
\hline \multirow[t]{5}{*}{1} & \multirow{5}{*}{$\begin{array}{l}\text { Arable land } \\
\text { including: }\end{array}$} & & 51.29 & 10.53 & 37.64 & 103.00 \\
\hline & & Cereals & 36.12 & 8.08 & 27.80 & 70.50 \\
\hline & & Root crops & 1.13 & 0.30 & 1.20 & 1.80 \\
\hline & & Fodder crops & 4.13 & 1.32 & 2.82 & 8.10 \\
\hline & & $\begin{array}{l}\text { Industrial } \\
\text { Vegetables }\end{array}$ & 9.92 & 0.83 & 5.82 & 22.60 \\
\hline 2 & \multirow{2}{*}{\multicolumn{2}{|c|}{$\begin{array}{l}\text { Grassland } \\
\text { Orchard and plantations }\end{array}$}} & 2.70 & 1.66 & 2.00 & 4.40 \\
\hline 3 & & & 0.18 & 0.03 & & 0.50 \\
\hline 4 & \multicolumn{2}{|c|}{ Arable land in total } & 54.17 & 12.22 & 39.64 & 107.90 \\
\hline
\end{tabular}


Continuing the assumed purpose of the thesis, the equipment with selected technical production inputs of farms providing agricultural production with a fixed replacement value of the machine park, expressed in thousands PLN $\cdot h a^{-1}$ UR, has been analyzed in Table 2. The work covered the most common agricultural equipment, i.e.: agricultural tractors, selfpropelled machines (harvesters), cars used in agricultural production and the remaining park used in production processes, i.e. plows, fertilizer spreaders, sprayers, etc. Replacement value of the machine park and annual use of the above-mentioned technical means were analyzed in groups of farms divided based on the area of the farm's cropland.

The replacement value of the machine park is one of the basic elements that specify the level of technical equipment of farms.

When analyzing Table 2, it was observed that in the majority of examined groups, the increase in the replacement value of machines and devices was noted.

On the basis of the studies carried out, the highest value was observed in farms with small areas, while the lowest value was noted in farms with large areas in 2011 and in 2016. The most intense difference in the replacement value was observed in small farms, where an increase by $41.71 \%$ greater than in 2011 was recorded. When analyzing Table 2, it is worth to mention that in the analyzed initial period in the group of small and medium-sized farms, no harvesters were registered, the owners of the largest farms only had this mean of production. The situation changed in the analyzed final period (2016). To sum up Table 2, it was observed that tractors have a clear lead over delivery trucks and other machines and devices that were used on farms in shaping the replacement value of the machine park, generating approx. $47 \%$ of the total value of the budget invested in technical production inputs in 2011 and $37 \%$ in 2016.

On the basis of the interview and numerical characteristics, it was stated that the agricultural equipment under the study is old especially in farms that have the smallest area and the annual use of machines is at a low level.

Table 3. Replacement value of machine park [PLN thousands $\mathrm{ha}^{-1} \mathrm{UR}$ ]

\begin{tabular}{|c|c|c|c|c|c|}
\hline \multirow[t]{2}{*}{ Item } & \multirow[t]{2}{*}{ Specification } & \multirow[t]{2}{*}{ On the average } & \multirow[b]{2}{*}{ small } & \multirow[b]{2}{*}{ medium-sized } & \multirow[b]{2}{*}{ large } \\
\hline & & & & & \\
\hline \multicolumn{6}{|c|}{ Year 2011} \\
\hline 1 & Cars & 1.49 & 5.13 & 1.35 & 0.84 \\
\hline 2 & Tractors & 3.36 & 7.14 & 3.45 & 2.52 \\
\hline 3 & Self-propelled machines & 0.84 & & & 1.61 \\
\hline 4 & Other & 1.41 & 3.60 & 2.05 & 0.51 \\
\hline 5 & In total & 7.10 & 15.87 & 6.85 & 5.48 \\
\hline \multicolumn{6}{|c|}{ Year 2016} \\
\hline 1 & Cars & 1.58 & 8.51 & 1.97 & 0.72 \\
\hline 2 & Tractors & 2.89 & 7.38 & 2.49 & 2.59 \\
\hline 3 & Self-propelled machines & 1.80 & 3.55 & 2.06 & 1.52 \\
\hline 4 & Other & 1.58 & 3.05 & 0.46 & 1.88 \\
\hline 5 & In total & 7.85 & 22.49 & 6.98 & 6.71 \\
\hline
\end{tabular}

Use of tractors during the year (Fig. 1) was also worth noticing. The smallest use in agricultural production (67 hour·year $\left.{ }^{-1}\right)$ and in services $\left(7\right.$ hour $\left.\cdot y e a r^{-1}\right)$ was in 2011 in small farms. The largest use, however, was in 2016 in large farms: production 502 hour $^{-}$year $^{-1}$, services 138 hour year $^{-1}$. 


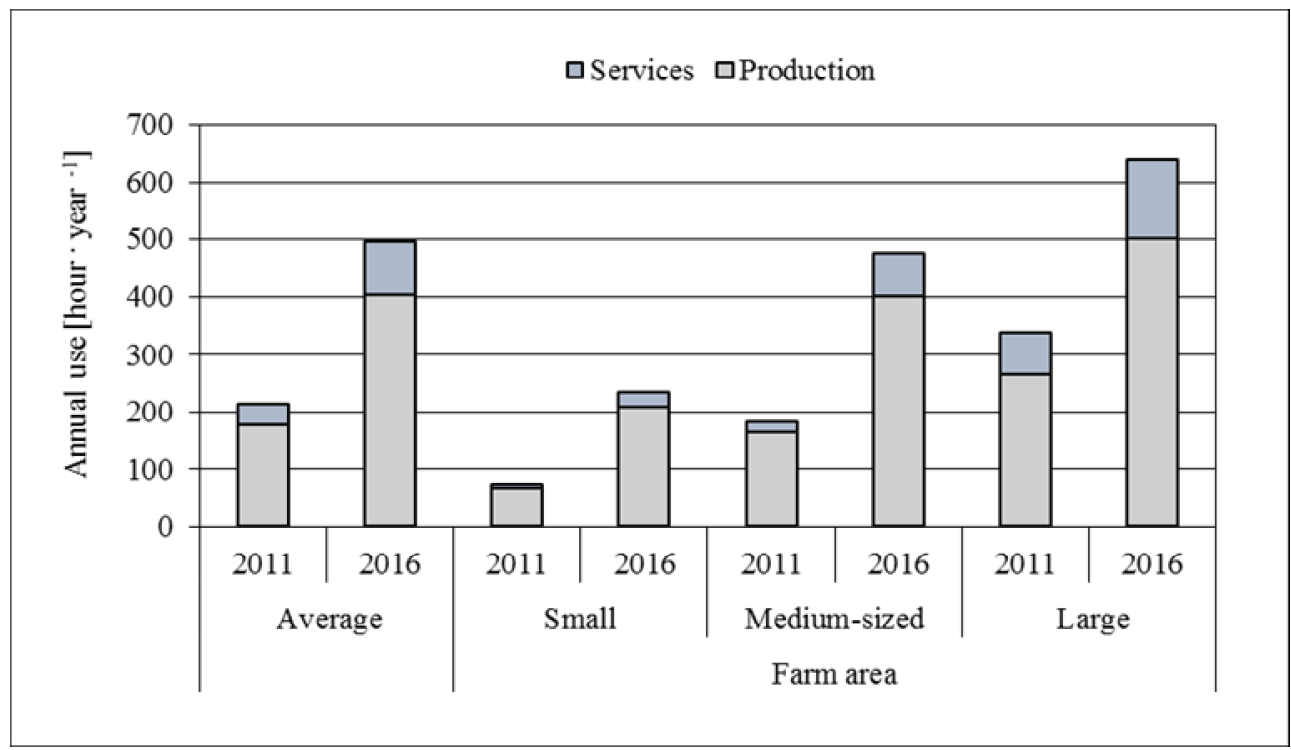

Fig. 1 Annual use of agricultural tractors [hour $\cdot \mathrm{year}^{-1}$ ]

To continue, Figure 2 presents values on labor productivity (labor efficiency) measured by the ratio of the value of clean production to the spent man-hours in agriculture. Figure below (Fig. 2) shows that the largest value of labor productivity was achieved by large farms. In 2011, this value was PLN 28.53 man-hour $^{-1}$, while in 2016, it increased to PLN $167.53 \cdot$ man-hour $^{-1}$. The lowest productivity was observed in small farms, in 2011 this value mounted to PLN 5.20 man-hour $^{-1}$, while in 2016 it increased to PLN 22.00 man-hour $^{-1}$. A significant increase in productivity was observed and it determined, among others, the quality of life, which was significantly improved with regard to clean production in the analyzed farms.

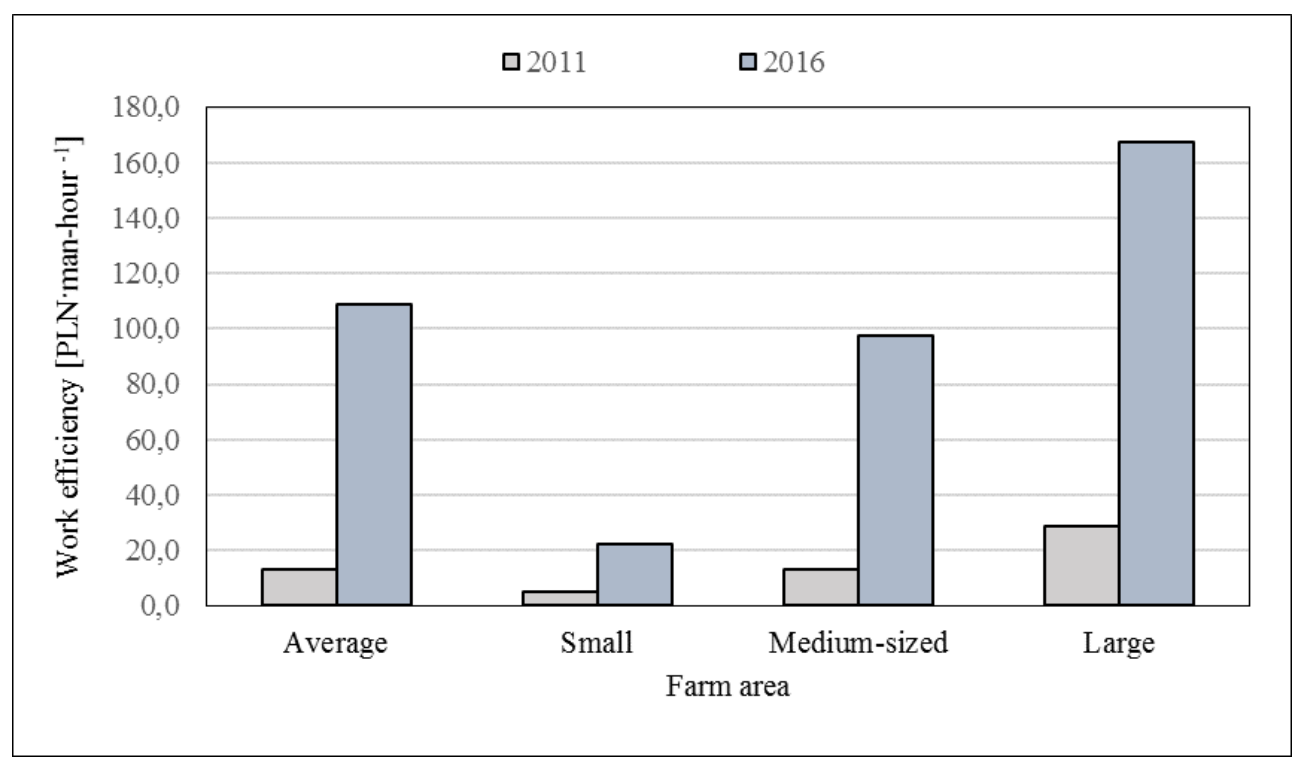


Fig. 2 Work efficiency in agricultural production $\left[\mathrm{PLN} \cdot \mathrm{man}^{\left.-h_{0} \mathrm{r}^{-1}\right]}\right.$

\section{Summary}

The purpose of the study was to determine the scale and importance of the investments in technical production inputs in the form of a replacement value of the machine park, made in agricultural activities with regard to improvement of their productivity.

The study proved a positive impact of the investment expenditures made with regard to the replacement value of the machine park on the increase in labor productivity in agriculture and the investments made in technical production inputs contributed to the processes of work substitution in the analyzed farms.

The analyzed farms had sufficient funds to finance investments regarding modernization of the machine park. Own funds and funds from the European Union were the main source of investment.

The studies carried out revealed that the highest replacement value of the machine park per hectare of cropland was noted in the smallest farms (1-20 ha) in both study periods. On the average, for all analyzed groups, the largest investments regarded self-propelled machines (harvesters) which resulted from the increased area of cereal plantations over the analyzed period by more than $60 \%$.

The increase in equipment in technical production inputs, expressed in the replacement value of the machine park, had an impact on the increase in the labor productivity index measured by the ratio of clean production to labor inputs in agriculture (man-hour). Proper management of production resources in agriculture resulted in the increase in the labor productivity index in all analyzed groups on the average by over $80 \%$. Replacement of the labor intensity of production with capital intensity clearly confirms economic theories on the increase in the effectiveness of agricultural activity, with the technological progress in the economic activity conducted.

\section{References}

1. M. J. Orłowska, Roczniki Naukowe SERiA, XVII 2, 189-195, (2015).

2. S. Tabor, Inżynieria Rolnicza, 10 85, (2006).

3. L. Latruffe, Competitiveness, Productivity andEfficiency in the Agricultural and AgriFood Sectors. OECD Food, Agriculture and Fisheries Papers, 30, (2010).

4. I . M. Sheldom, Journal of Agricultural and Applied Economics. 49 1, 1-44, (2017).

5. Z. Kowalczyk, M. Cupial, Estimation methods of the agricultural equipment value with regard to evaluation of Alina carrot harvester. Contemporary Research Trends in Agricultural Engineering, BIO Web Conferences, 10(01011), (2018).

6. K. Grotkiewicz, M. Kuboń et al. ,Postęp naukowo-techniczny w procesie modernizacji polskiego rolnictwa i obszarów wiejskich. Agricultural Engineering, (2013).

7. A. Szelagg-Sikora, Technical modernization of agricultural farms aided with European Union funds as a precondition for development of producer groups. Polish Society of Agricultural Engineering, (2013).

8. Z. Kołoszko-Chomentowska, Roczniki Naukowe, XVIII 3, 178-183, (2016).

9. Central Statistical Office, Statistical Yearbook of the Republic of Poland, Warszawa, (2017).

10. A. Sadowski, Zrównoważony rozwój gospodarstw rolnych z uwzględnieniem wplywu Wspólnej Polityki Rolnej Unii Europejskiej. Wyd. Uniwersytetu Przyrodniczego w Poznaniu, (2012). 
11. W. Czubak, A. Sadowski, Journal of Agribusiness and Rural Development, 2 32, 45 46, (2014).

12. Central Statistical Office, Concise Statistical Yearbook of Poland, Warszawa, (2019).

13. Central Statistical Office, Statistical Yearbook of the Republic of Poland, Warszawa, (2018a).

14. Central Statistical Office, Concise Statistical Yearbook of Poland, Warszawa, (2018b).

15. K. Grotkiewicz, A. Latawiec, M. Kuboń, A. Szelag-Sikora and M. Niemiec, Institute of Economic Research Working Papers, 30, 1-11, (2017).

16. A. Szelag-Sikora, M. Cupial and M. Niemiec, Productivity of farms in the aspect of various activity forms, In: Huyghebaert, B., Lorencowicz, E. and Uziak, J. (eds), Farm Machinery and Processes Management in Sustainable Agriculture, 94-98, (2015).

17. J. Góral, W. Rembisz, Wieś i Rolnictwo 4 177, (2017). 